\title{
E-learning formation retrospective analysis in the theory and practice of education
}

\author{
D.S. Dmitriev ${ }^{1 *}$, and D.S. Dmitrieva ${ }^{2}$ \\ ${ }^{1}$ Samara National Research University, Samara, Russia \\ ${ }^{2}$ Samara National Research University, Samara, Russia
}

\begin{abstract}
The article identifies and describes the retrospective analysis stages of the E-learning tools use problem in the theory and practice of education. Based on the analysis of trajectory "infrormatization - open education - information and education environment - E-learning - Elearning tools" and retrospective analysis and scientific output methods the actuality and objectivity of teachers' training e-learning use in professional activity problem is substantiated.
\end{abstract}

\section{A problem statement}

The post-industrial society education system reforming tasks demanded changes in the university educational process teaching and organization means and methods. The important thing is that the means and methods should be adequate to the globalization, integration and informatization processes on the basis of the state policy principles in the field of education informatization. That caused the emergence of a new type of education open, based on free unlimited access to educational resources. Open education can be implemented in the new information and educational environment context that integrates electronic information resources, information and communication technologies. E-learning as a new educational form is fixed in the fundamental normative act - the Federal Education Law (№273 dated December 29, 2012). The e-learning potential development contributes to the students' professional training quality increase, the educational institution competitive advantages increase by attracting new pedagogical and human resources to the educational programs implementation. That also develops the educational organization brand awareness in the information space. The starting condition for successful open education is the university teachers' preparation to use e-learning tools in their professional activity. The e-learning tools main user in the open education implementation process is the teacher, who assumes managing function of the students' adaptation process to the electronic information and educational environment.

\footnotetext{
*Corresponding author: ipcs-profped@yandex.ru
} 


\subsection{The objective of the work}

Nowadays, in pedagogical science, the considerable attention is focused on the learning methods and technologies improvement. This is due to all activity spheres qualified personnel training need in the conditions of dynamically changing economic and social environment. Education reforming and modernization in high school institutions is inextricably linked with teaching information technologies use. It creates conditions for new research directions of the educational process organization means. The information technology rapid development and the global Internet spread, called informatization, has actualized the problem of the economic sectors and education development. Researchers consider informatization as a process in which social, technological, economic, political and cultural mechanisms are not just connected, but literally fused together. From a technological point of view, informatization is understood as the labor activity technical and technological equipment in the production and management field. From another point of view, informatization can be viewed as a process that affects all spheres of human activity and the person himself (his knowledge, interests, and development). The foundation for the education informatization development is the education computerization, which gave rise to a new direction in innovative pedagogy [1]. Education informatization is taken for purposeful activity for the information and communication technologies development and implementation in various fields [2]: in the educational process to prepare citizens for life and work in the conditions of the modern information society; in the management of the education system to improve the efficiency and quality of process management; into methodological and scientific-pedagogical activities to improve the quality of teachers' work [3].

Education informatization is taken not only as a process, but also as the pedagogical science field, focused on providing the education sector with scientific and pedagogical, educational, methodological, software and technological developments methodology, technology and practice for the creation and optimal use in order to implement the information and communication technologies didactic possibilities in comfortable and health-saving conditions [4]. At the same time, the education informatization is considered as the scientific knowledge transfer-integrative area [5]. Education informatization and educational technologies integration tendencies are becoming research objects in pedagogical science: the education informatization process is studied as a natural step in the pedagogical informatics development [6]; education is viewed as the personality formation social process that requires informatization, and the knowledge acquisition and assimilation in education is studied on the basis of the relations model "data-information-knowledge" [7]. The education informatization trend in the society globalization context has led to the new education type emergence that is called open. Open education is understood as the content formation ideology, based on the free information modules banks creation, which serve as the basis for the new training courses construction [8]. In professional pedagogy, open education is very often viewed from the methodological point of view. At the same time, researchers pay attention to the organizational and managerial features of this definition. The open education global goal is to prepare learners to participate in the social and professional activity fields in the information society. The open education principles can be implemented in a new learning information and educational environment. This environment integrates electronic information resources; electronic educational resources; a set of information technologies, communication technologies, corresponding technological means. When designing an information and educational environment, taking into account the requirements of federal state educational standards (FSES), each student must be provided with access to information technology educational resources. In pedagogical practice, the information and educational environment concept is defined as an anthroposophically relevant information environment designed to reveal teacher and 
student the creative potential and talents. Also the information and educational environment is electronic information resources, electronic educational resources, set of information technologies, communication technologies, and appropriate technological means.

The education informatization implementation trend allows creating the world education powerful single center, which is the foundation of open education. The education informatization trend and the information and educational environment implementation led to the researchers' attention to educational activities from the standpoint of information and communication technologies and the actualization of E-learning [9]. E-learning has become the open education implementation mean within the framework of the information and educational environment building. E-learning is understood as the educational activities organization with the use of information contained in databases and used in the implementation of educational programs and information technologies, technical means, as well as information and telecommunication networks that ensure the this information transmission through communication lines, interaction between students and teachers. Also, when defining E-learning, attention is focused on its multimedia content, which makes it possible to define E-learning as an educational process that is implemented with the use of the Internet and multimedia technologies.

E-learning is an important component of the educational process. This fact is also confirmed by the fact that the regulatory and legal framework that regulates e-learning itself in the educational process is developing. E-learning is presented not only as the open education implementation means, but also as a new form of learning. At the same time, Elearning tools are becoming a tool for implementing e-learning as a new form within the information and educational environment. Such means catalyze a change in the world and teaching principles, introducing technical foundations into pedagogy, giving them a new educational meaning. That is why teaching with the help of electronic means is becoming an innovative form of educational technologies development nowadays.

E-learning tools can be educational tools that implement the information technology capabilities: provide educational information using multimedia technology; provide feedback with the user during interaction, monitor the learning and progress results in the study; to automate the information and methodological support processes of the education and educational institution organizational management. This logic E-learning tools considering requires the teacher personal qualities adaptation, because the teacher is the main user of E-learning tools in the open education implementation. The teacher becomes not just a user of the tools, but also inherits the administrator's functions, which allow taking into account the author's approach to the educational subjects implementation, filling them with additional functionality focused on adapting students to work with the tools, and taking into account the teachers personal characteristics.

\section{Materials and the results of the research}

For E-learning tools place determination in the teacher professional activity, as well as the requirements for the teacher professional and personal qualities, let us turn to a retrospective analysis of the using E-learning tools use problem in the educational process.

Key aspects of the retrospective analysis are presented in Table 1. 
Table 1. Stages of E-learning tools use in the theory and practice of education.

\begin{tabular}{|c|c|c|c|c|c|}
\hline Stage & $\begin{array}{l}\text { Purpose of } \\
\text { education }\end{array}$ & $\begin{array}{c}\text { Type of } \\
\text { education }\end{array}$ & Principles & Tool & $\begin{array}{c}\text { Teacher } \\
\text { personality } \\
\text { traits } \\
\end{array}$ \\
\hline $\begin{array}{l}\text { Stage 1 } \\
\text { (XIX } \\
\text { century - } \\
1920 \text { s) }\end{array}$ & $\begin{array}{l}\text { Development of } \\
\text { students non- } \\
\text { standard skills }\end{array}$ & $\begin{array}{l}\text { Adaptive } \\
\text { distance } \\
\text { education }\end{array}$ & $\begin{array}{l}\text { Availability } \\
\text { Distance } \\
\text { Didacticity }\end{array}$ & $\begin{array}{c}\text { Tests and } \\
\text { assignments in mail } \\
\text { letters (Isaac Pitman } \\
\text { training system) }\end{array}$ & $\begin{array}{l}\text { Ability to } \\
\text { adapt } \\
\text { knowledge } \\
\text { (content) in } \\
\text { an } \\
\text { acceptable } \\
\text { broadcast } \\
\text { version } \\
\end{array}$ \\
\hline $\begin{array}{l}\text { Stage 2 } \\
(1920 \text { s - } \\
1960 \text { s })\end{array}$ & $\begin{array}{l}\text { Labor saving in } \\
\text { education; } \\
\text { simplification of } \\
\text { teaching } \\
\text { activities; } \\
\text { increasing the } \\
\text { acquiring skills } \\
\text { speed }\end{array}$ & $\begin{array}{c}\text { Effective } \\
\text { universal } \\
\text { education } \\
\text { Total } \\
\text { mechanizati } \\
\text { on }\end{array}$ & $\begin{array}{c}\text { Technologiz } \\
\text { ation } \\
\text { "Paperless" } \\
\text { documentati } \\
\text { on } \\
\text { Automation }\end{array}$ & $\begin{array}{c}\text { Movies and } \\
\text { television } \\
\text { broadcasts } \\
\text { (Pittsburgh's PBS } \\
\text { WQED); } \\
\text { standardized tests } \\
\text { ("Automatic } \\
\text { teacher"); offline } \\
\text { knowledge bases } \\
\text { (prototype memex) }\end{array}$ & $\begin{array}{c}\text { Ability to } \\
\text { broadcast } \\
\text { information } \\
\text { (knowledge) } \\
\text { in a } \\
\text { compact } \\
\text { form; } \\
\text { broadcastin } \\
\text { g practice- } \\
\text { oriented } \\
\text { knowledge; } \\
\text { improving } \\
\text { the skills of } \\
\text { working } \\
\text { with } \\
\text { computer } \\
\text { systems }\end{array}$ \\
\hline $\begin{array}{l}\text { Stage 3 } \\
(1960 \mathrm{~s}- \\
1990 \mathrm{~s})\end{array}$ & $\begin{array}{l}\text { Increasing the } \\
\text { training } \\
\text { intensity; } \\
\text { development of } \\
\text { complex human } \\
\text { abilities; joint } \\
\text { development of } \\
\text { knowledge; } \\
\text { development of } \\
\text { education in } \\
\text { remote areas }\end{array}$ & $\begin{array}{l}\text { Multimedia } \\
\text { education }\end{array}$ & $\begin{array}{c}\text { Informatizat } \\
\text { ion } \\
\text { Visibility } \\
\text { Suggestiven } \\
\text { ess } \\
\text { Scientificne } \\
\text { ss } \\
\text { Consistency }\end{array}$ & $\begin{array}{l}\text { Multimedia class } \\
\text { (Don Bitzer class at } \\
\text { the University of } \\
\text { Illinois); software } \\
\text { training systems } \\
\text { (PLATO, onLine } \\
\text { System, } \\
\text { COURSEWRITER, } \\
\text { IBM1500, TICCIT, } \\
\text { EXTEND, COMIT, } \\
\text { Successmaker K-12, } \\
\text { CAFÉ, SumTotal } \\
\text { Systems, CMIS, } \\
\text { etc.); } \\
\text { automated } \\
\text { processing of test } \\
\text { results (device at the } \\
\text { University of } \\
\text { Alberta); } \\
\text { satellite television } \\
\text { training systems } \\
\text { (Telesecundaria) } \\
\text { Computer training } \\
\text { devices with } \\
\text { graphical interface } \\
\text { (KiddiKomputer); } \\
\text { distance and e- }\end{array}$ & $\begin{array}{l}\text { Ability of } \\
\text { the learning } \\
\text { process } \\
\text { intensifying } \\
\text { with the } \\
\text { help of } \\
\text { hardware } \\
\text { and } \\
\text { software; } \\
\text { develop } \\
\text { additional } \\
\text { abilities; } \\
\text { understand } \\
\text { the } \\
\text { information } \\
\text { content of } \\
\text { software } \\
\text { components }\end{array}$ \\
\hline
\end{tabular}




\begin{tabular}{|c|c|c|c|c|c|}
\hline Stage & $\begin{array}{l}\text { Purpose of } \\
\text { education }\end{array}$ & $\begin{array}{c}\text { Type of } \\
\text { education }\end{array}$ & Principles & Tool & $\begin{array}{c}\text { Teacher } \\
\text { personality } \\
\text { traits }\end{array}$ \\
\hline & & & & $\begin{array}{c}\text { courses ("college } \\
\text { without walls" at } \\
\text { Coastline } \\
\text { Community } \\
\text { College, CALC, } \\
\text { etc.); applied } \\
\text { educational } \\
\text { software products } \\
\text { (TLM, Cyclops, } \\
\text { LISTSERV, etc.); } \\
\text { hypertext }\end{array}$ & \\
\hline $\begin{array}{l}\text { Stage } 4 \\
(1990 \mathrm{~s} \\
\text { years - } \\
2000 \mathrm{~s})\end{array}$ & $\begin{array}{c}\text { Availability of } \\
\text { knowledge; of } \\
\text { the learning } \\
\text { process } \\
\text { interactivity }\end{array}$ & $\begin{array}{c}\text { Open } \\
\text { education, } \\
\text { distance } \\
\text { education }\end{array}$ & $\begin{array}{c}\text { Distance, } \\
\text { Interactivity } \\
\text { Efficiency } \\
\text { Objectivity } \\
\text { Harmony } \\
\text { Activity } \\
\text { Individualit } \\
\text { y }\end{array}$ & $\begin{array}{l}\text { Integrated virtual } \\
\text { educational Internet } \\
\text { systems and virtual } \\
\text { educational } \\
\text { environments (The } \\
\text { Smart Board, } \\
\text { Training } \\
\text { Administrator, } \\
\text { WOLF, CECIL, } \\
\text { UnisANet, } \\
\text { Desire2Learn); } \\
\text { distance systems } \\
\text { (WeBWorK), } \\
\text { virtual educational } \\
\text { centers (Microsoft } \\
\text { MOLI); web } \\
\text { trainings and online } \\
\text { educational courses } \\
\text { (The Open } \\
\text { University and the } \\
\text { University of } \\
\text { British Columbia, } \\
\text { etc.) }\end{array}$ & $\begin{array}{l}\text { Ability to } \\
\text { use } \\
\text { interactive } \\
\text { educational } \\
\text { tools; } \\
\text { process } \\
\text { large } \\
\text { amounts of } \\
\text { knowledge }\end{array}$ \\
\hline $\begin{array}{l}\text { Stage } 5 \\
(2000 \mathrm{~s}- \\
\text { the } \\
\text { present })\end{array}$ & $\begin{array}{l}\text { Improving the } \\
\text { Internet } \\
\text { education } \\
\text { quality; E- } \\
\text { learning } \\
\text { principles } \\
\text { implementation } \\
\text { in traditional } \\
\text { education }\end{array}$ & $\begin{array}{l}\text { Electronic } \\
\text { (digital) } \\
\text { education }\end{array}$ & $\begin{array}{l}\text { Adaptability } \\
\text { Optimality } \\
\text { Innovativen } \\
\text { ess } \\
\text { Efficiency } \\
\text { Continuity } \\
\text { Freedom to } \\
\text { choose the } \\
\text { pace and } \\
\text { time of } \\
\text { learning }\end{array}$ & $\begin{array}{c}\text { Application } \\
\text { software products } \\
\text { used for educational } \\
\text { purposes (YouTube, } \\
\text { social networks); } \\
\text { full-featured } \\
\text { educational process } \\
\text { management } \\
\text { systems (SkillSoft); } \\
\text { WE-learning } \\
\text { resources; Massive } \\
\text { Open Online } \\
\text { Courses (MOOCs) }\end{array}$ & $\begin{array}{l}\text { Ability to } \\
\text { choose and } \\
\text { apply } \\
\text { innovative } \\
\text { educational } \\
\text { methods; } \\
\text { focus on } \\
\text { online } \\
\text { learning; } \\
\text { ability to } \\
\text { apply e- } \\
\text { learning } \\
\text { tools }\end{array}$ \\
\hline
\end{tabular}

The first stage of E-learning tools use in the educational process. The basic principles that served as the basis for the E-learning creation were laid long before the computers and information and communication technologies advent. The modern principles of E-learning and distance learning were laid down in the 19th century by Professor Isaac Pitman. He taught disciplines in the UK by correspondence method. The teaching method was implemented as follows: assignments on the course topics were sent to students by mail; 
pupils, having completed their homework, sent the results in a reply letter to the school, and then waited for a response from the teacher with the results of the check and new homework, also, by mail.

The second stage of E-learning tools use in the educational process. So, the first signs of E-learning were laid at the end of the 19th century. Further, the attention of teachers was paid to the development of technical means. The technical means integrating process into the educational process took place during the 20th century. Fully technical means have become the pedagogical tools integral part by the end of the 20th century. In the early 1920s, Ohio State Professor of Psychology Sidney Pressey developed a new pedagogical tool for drilling procedures teaching that was intended to guide the educational process. The tool made it possible to integrate real practical tasks into a theoretical educational course. The device invented by the professor resembled a typewriter with a window that showed a question with four possible answers. The student pressed the button with the suggested answer, and the machine compared the student's answer with the correct answer to the question, and then wrote the given answer on the counter at the back. The next question was then shown to the student. At the end of the test, the professor took the results out of the car, re-ran the answer sheet, and the number of correct answers was displayed on the machine counter.

An important stage in the creation of e-learning tools was the World War II, when it was necessary to train a significant number of recruits every day to prepare for participation in hostilities. In 1945, Vannevar Bush, in his research paper, described a hypothetical prototype of an educational device - memex, in which a student can store his notes, contacts, books [11]. In the 50s of the XX century, researchers at the University of Indiana worked on the author's teaching system creation. Burrhus Frederic Skinner, analyzing the insufficient number of highly qualified teaching staff to fill all available vacancies for teaching students, stated the fears of the American educational system development. The technology invented by Burrhus Frederic Skinner is called programmed learning. Gordon Pask and Robin McKinnon-Wood developed SAKI (Self-Adapted Keyboard Instructor) in 1956, the first commercially available adaptive educational system that taught typing skills with a specialized keyboard. Between 1956 and 1958, Berkley Harvey professor of physics Whyte lectured at 163 universities to showcase the Pittsburgh's PBS WQED station.

For the first time, modern multimedia tools were used as pedagogical tools: each traditional lecture was filmed and then disseminated in dozens of educational institutions with help of public television channels.

The third stage of E-learning tools use in the educational process. Traditionally, it is believed that the E-learning development begins in the 60s of the XX century: Professor Don Bitzer at the University of Illinois created a specialized multimedia class based on a computer terminals small network of the research computer educational laboratory, which was called PLATO $[12 ; 13 ; 14]$. During lectures, students could access materials on the lesson subject, which were recorded using video or audio technical means, taking into account the multimedia foundations laid down in the previous stage of genesis. PLATO became the first e-learning system in its modern sense. In the early 1960s, Stanford University professors of Psychology proposed a pedagogical experiment using information technology to teach math and reading to elementary school students. The experiment results became the basis for the gifted students programs support creation based on integrated Elearning tools. Douglas Engelbart in his 1962 research paper laid out the basics of using computer technology to increase the learning intensity. Engelbart and his colleagues at the Stanford Research Institute have begun the information system development to enhance human abilities in order to improve the educational activities effectiveness. The oNLine System (NLS), launched in 1968, has become the primary E-learning tool for Engelbart's vision. 
Ivan Sutherland, Ph.D., professor at the University of Massachusetts, published "Sketchpad: A Man-machine Graphical Communications System" in 1963, which is considered the first complete instructional manual for an educational system with a fullfledged graphical user interface. Sketchpad is a computer-specific E-learning tool that transforms a student's computer into an interactive educational workplace. In 1965, IBM and Science Research Associates conducted and presented a series of scientific pedagogical studies in the educational process and developed the first interactive online learning system COURSEWRITER for the IBM 1500. The system included management functions and introduced a powers distribution innovative system (system of roles), designed for three user groups: teacher, educational system administrator and student.

At the University of Alberta, a dedicated education research unit was created in 1967, which designed and tested an automatic electronic grade scoring device based on tape and an IBM computer. This educational tool was significant not so much from the point of view of the software tools development and participation in pedagogy as, if possible, their application in the management of educational activities. At the same time, a specialized drilling training system was developed at the University of Alberta for the Faculty of Engineering. In 1968, the Mexican government decided to develop secondary schools in rural remote areas. For this purpose, the Telesecundaria system was designed on the basis of satellite TV. Originally, each of the 304 classrooms, attended by more than 6,500 students, was equipped with a satellite TV dish and black and white TV. Telesecundaria is currently one of the few systems still in use in education. With the help of Telesecundaria, more than a million people are currently studying in Mexico in various remote locations in Mexico and Central America. In 1968, MITER Corporation began to develop the latest computer-controlled educational interactive system using all modern developments: time sharing, television integration. These components were a fully functional computer system characterized by low cost, high quality teaching and a high degree of individuality due to the interactivity principle. The invention of ARPANET in 1969 characterizes further revolutionary changes in the development of all information technologies. ARPANET information and communication structure; network, which is the basis for the creation of the modern global Internet. Stanford University continued the use of television broadcasting in education: university staff organized university television and broadcast several educational courses with its help. Bernard Luskin was the founder of the computer technologies complex use in the educational process. Bernard Luskin's doctoral work focused on identifying and removing barriers in the computer-assisted developing context teaching. Further dynamic introduction of computers into the educational system of California and the United States is associated with the Bernard Luskin name. It was under his leadership that a research project was launched on the potential need for distance education in the future. Under the leadership of Bernard Luskin, community leaders and professional educators developed a detailed action plan that predicted the various software and technological innovations emergence, many of which are currently being used in the educational system. The attention of the Canadian educational system in 1970 was also drawn to the area of innovative software technologies. So, at this time, computers were used in elementary schools in the cities of Saskatoon, Saskatchewan for the first time.

In the $70 \mathrm{~s}$, and then in the $80 \mathrm{~s}$ of the XX century, the active development of distance learning was observed in Canada and in the UK. In 1976, Bernard Luskin initiated the "college without walls" creation at Coastline Community College with the use of a television station. By the mid-1980s, access to course content had become possible in a large number of colleges. At this time, the first studies appeared on the topic of E-learning tools and their role in the educational process. Cassandra B. Whyte noted the E-learning systems increasing role in higher education, believing that the information technology software products introduction in education is the next step in the "educational evolution" 
$[15 ; 16]$. In her opinion, this process is inextricably linked with the development of computers themselves: from unproductive and cumbersome, which were very difficult even to fit in a college classroom, to portable productive devices (for example, laptops, which were more convenient) $[15 ; 16]$. Cassandra B. Whyte in her study cited evidence that the trend towards minimizing the size of computing devices will continue.

The fourth stage of E-learning tools use in the educational process. In the early 90s, The Open University and the University of British Columbia made a breakthrough in educational tools by using the Internet. They began to use web-based training and distance learning courses online. Since the inception of the Internet (WWW), teachers of educational organizations have begun to actively use modern technologies in their professional teaching activities. The first multi-object-oriented sites began to appear, which were a virtual system for creating courses. Correspondence schools, pioneered by the University of Phoenix back in the 80 s of the XX century, began to show great interest in online learning.

Johndan Johnson-Eilola in 1991 described a complete end-to-end support for virtual space - The Smart Board. According to Johndan Johnson-Eilola, The Smart Board was an analogue of a kind of tablet-projector with a convenient display, i.e. some clever surface to work with. The basis for the such system invention was an attempt to understand how participants in the educational process behave in the information space, as well as how information spaces affect the provision of educational services for users-participants. The system was based on three main functions: the ability to work with large amounts of information; work with an information space offering active cooperation; dynamism of the contingent of the system. Thus, according to Johndan Johnson-Eilola, users have the opportunity to engage in direct manipulation - to use the system in a way that suits them. The new information space implies the presence of at least several users. In 1994, the first online higher school, CompuHigh, appeared in the United States. With the development of the Internet technologies and the webcams advent, teachers could record their lectures on their own and simply upload them to the network on site pages [17]. With this implementation, education became even more accessible.

Arnold Pizer and Michael Gage of the University of Rochester (Department of Mathematics), in 1995, developed the WeBWorK project, which allows for use in teaching mathematics and solving homework problems in a distance form. Steve Molyneux at the University of Wolverhampton UK developed the WOLF (Wolverhampton Online Learning Framework), one of the first E-learning systems in the UK. In 1995, Murray Goldberg at the University of British Columbia, based on the general trend in the use of E-learning systems, developed and began to use the WebCT system, which was fully operational in 1996. In parallel with this, The University of Auckland Business School began to use the CECIL (computer supported learning or CSL). Glenn Jones, Chairman and Bernard Luskin launched a fully accredited web-based university - Jones International University in 1996. In 1997, Steven Narmontas introduced a small group of Western New England College educators who were developing a virtual e-learning course, The Manhattan Project. The software allowed teachers to submit files to a website for their students. The earliest version of The Manhattan also supported several discussion groups and a private messaging subsystem creation, from which the offshoot, The Manhattan Virtual Classroom, was created. Ian D. Thompson in 1998 at the University of Strathclyde created a version of the SPIDER system for the school of pharmacists. Ian Reid at the University of South Australia created a version of UniSAnet, a home virtual learning environment. In 1999, John Baker the University of Waterloo the student, created E-learning system for the Desire2Learn Faculty of Engineering and Mechanical Engineering. The new educational training systems global development as new E-learning tools had been developed, the functionality and capabilities of which became more complex and increased. 
The fifth stage of E-learning tools use in the educational process. The E-learning emergence is a significant event in the educational technologies and new educational tools development available for the growing need for education. The need to improve access to educational opportunities has allowed students who want to study at a particular educational institution, but cannot do it face-to-face because of the large distances from their residence place, to simply go online and start their studies through a virtual connection. The global spread of information technologies in education has turned them from a tool that performs the additional assistance function in pedagogical activity into one of the most significant tools (mechanisms) that affect the development of education. The Elearning tools proliferation laid the foundation for subsequent changes in the educational process.

In the early 2000s (2000-2001), there were two global "breakthroughs": on the one hand, the revolution in connection with the emergence of the Internet educational systems, and on the other hand, it is the recession associated with the Internet. These factors created the conditions for the migration of curricula and materials from face-to-face meeting with a teacher to online. In accordance with the logic of the E-learning systems development, there are several opportunities for the online learning implementation. It is possible to implement the educational process with the help of the educational tools Rapid E-learning (transition from PowerPoint to Flash), business stimulation, modeling, imitation, audio, video, as well as using virtual interactive elements of the educational process.

Educational organizations consider the Internet as information store, with the help of which it is possible to provide materials to students; as an interactive environment that provides remote interaction "teacher-student"; as a means of distributing the key tools of the educational process. Currently, learning tools are integrated into a large number of information technology products: from YouTube to complex learning management systems, content management systems. The Internet technologies evolution leap has led to the fact that now there is an opportunity to use this material using mobile phones and other gadgets.

In addition, the original E-learning concepts have changed. In the early days of the Internet global expansion, companies aimed to move all learning materials to the Internet rapidly; SkillSoft is a pioneer in this trend. The educational process building based on the E-learning tools integration today is significantly different: the teacher uses online films, video games and virtual reality as educational tools. As the demand for more and more applications increased, the number of industry tools also grew rapidly.

Nowadays, there is a development of "social learning", "non-formal learning" and "collaborative learning" called WE-learning. With the help of WE-learning, the transition to the knowledge joint development is realized. The training organization takes place online: a dynamic environment affects the participants in the educational process, changing the process itself. WE-learning imposes on the teacher a significantly greater functionality that differs from the educational process traditional meaning. The teacher in such systems should be the organizer or leader of the collaborative learning, and not necessarily the author or creator. At the same time, WE-learning does not aim at the complete programs elimination used in the traditional educational process.

WE-learning is not intended to eliminate the formal instructional design need and teacher-led learning. These systems serve as a significant addition to and improve the traditional education quality. In many cases, formal training becomes more effective: this type of organization opens up a new form of corporate training, changes the style of its delivery, while simultaneously creating a market for many new educational tools and platforms. In WE-learning, the learning process is based on the use of portable mobile devices, tablets, etc., which can eliminate the need to use only a personal computer. In addition, WE-learning changes the behavior style in the field of culture and leadership [18]. 
Education with the computer technology use is represented by a complex consisting of teaching methods with a computer; methods of learning processes computer control; teaching methodology based on the Internet technologies; web-based teaching methods. The methodological complex advantages are: time allocation for individual lessons, getting rid of training session's repetition, ensuring the education quality [19].

The E-learning tools development could not but affect the educational process in the Russian Federation, following the general modernization of education in the world. Today it is difficult to name the exact date of the first introduction of E-learning tools in Russia, but it can be noted that nowadays it is used more and more often in the educational process. This situation is primarily due to the information technologies development abroad (in Europe, USA, and Japan): the computer technology evolution continues for a rather long period of time, starting from the 70s-80s of the XX century and up to the present.

Since the 90s, information and communication technologies and interaction means have been used in the Russian Federation. That is why E-learning tools in Russia are still notable for their comparative novelty in educational technologies and are actively developing at the present time.

The software part of E-learning tools is represented by both simple static HTML pages (with static educational material, for which it is enough to have the Internet and a simple browser), and more complex learning management systems and educational content used in corporate networks of educational organizations.

The successful E-learning implementation in the system of a higher educational institution is based on the correct software choice that meets the various requirements that are set in the process of educational process implementation. These requirements are determined by the student's needs, the teacher's needs. Also the system administrator functionality is important. They solve the problems of installation control, software system management, qualitative and quantitative control and the educational process output parameters analysis.

Modern E-learning tools can be classified as follows:

1. Author's software development.

2. Learning management systems.

3. Content management systems.

4. Management systems for educational content.

\section{Conclusions}

The retrospective analysis of ideas about E-learning in the university teacher professional activity showed the E-learning systems evolution and made it possible to establish that Elearning has transformed from a theoretical and technical concept into a new type of education. The genesis of ideas about E-learning made it possible to identify five main stages in the education informatization and the transformation of its types based on the development and diversification of the principles: from accessibility, distance and didacticity to interactivity, efficiency, individuality, optimality and freedom to choose the pace and time of learning. At the same time, the E-learning tools themselves have turned from technical to pedagogical tools. The E-learning tools evolution at different stages is becoming the education development indicator. The E-learning tools development requires the traditional learning tools and innovative ones integration. The basis for the E-learning tools use is based on the basic didactic principles: visualization of teaching; distributed and interactive teaching material; multimedia presentation of educational information; adaptability to the student's personal characteristics of the, manufacturability and accessibility. 
Also, the genesis of ideas about E-learning showed that the logic of its development has always been based on the ideas of educational process automation and optimization, the objectivity of its results assessing. The experience of innovative teaching methods developing and applying has always required teachers to improve their qualifications, and in the case of mastering electronic learning technologies, to integrate methodological knowledge and technological skills [20]. In the context of vocational education modernization and improvement, the problem of information technologies, E-learning tools use is being actualized, which requires the educational process result clarification and the development of methodological approaches to obtaining it.

One of the key tasks is the creation of open, networked universities and consortia, which is currently impossible without the E-learning use as an organizational form, and the requirements of world rankings for leading educational institutions impose mandatory conditions on the availability of online courses, the E-learning tools use in the educational process, and distance learning technologies [21]. The new goals of the educational process reforming in accordance with the FSES set the task of the educational process modernizing in terms of developing and implementing progressive methods of the educational process organizing, innovative educational technologies that meet the requirements of the international educational environment. The educational institutions heads and educational process managers in universities are faced with the tasks of E-learning organizing and distance learning technologies introducing; their scientific and methodological support, coordination and examination of electronic educational resources of E-learning. The main task should be the preparation of a university teacher for the E-learning tools use.

\section{References}

1. Yu. Santos, Nurse Education Today 72, 12-17 (2019)

2. Zh. Aiqun, Procedia Computer Science 131, 683-690 (2018)

3. J. Martins, Telematics and Informatics Telematics and Informatics 38, 182-193 (2019)

4. I.V. Robert, Chelovek I obrazovanie 1 (30), 14-18 (2012)

5. I.V. Robert, Pedagogicheskoe obrazovanie v Rossii 8, 110-119 (2014)

6. D.Yu. Ilyina, Izvestia: Herzen University Journal of Humanities \& Sciences 12, 5, 285-293 (2005)

7. V.Ya. Tsvetkov, Mezhdunarodnyi zhournal ekperimental'nogo obrazovaniya 4-2, 108-111 (2013)

8. I. Roedera, M. Severengizb, R. Starka, Procedia Manufacturing 8, 81-88 (2017)

9. A.E. Starichenko, Pedagogicheskoe obrazovanie 2, 143-145 (2014)

10. B. Park, R. Moreno, T. Seufert, Computers in Human Behavior 27 (1), 5-10 (2011)

11. V. Bush, As we may think, access mode: https://www.theatlantic.com/magazine/archive/1945/07/as-we-may-think/303881/

12. S. Smith, B. Sherwood, Science 192 (4237), 344-352 (1976)

13. K. Jack, C. Hamshire, Nurse Education in Practice 37, 141-145 (2019)

14. E. Van Meer, PLATO: From Computer-Based Education to Corporate Social Responsibility, access mode: / http://www.cbi.umn.edu/iterations/vanmeer.html

15. C.B. Whyte, Journal of College Student Personnel 28 (1), 5-7 (1987)

16. C.B. Whyte, Journal of College Student Personnel 30, 86-89 (1989)

17. U. Haque, The architectural relevance of Gordon Pask, access mode: https://www.haque.co.uk/papers/architectural_relevance_of_gordon_pask.pdf 
18. S. Goyal, Journal of Education and Learning 6 (2), 239-242 (2012)

19. I. Duykarev, E. Karavaeva, E. Kovtun, Bilbao: Deusto University (2013)

20. L.A. Vitvitskaya, V.V. Kuznetso, Vestnik of Orenburg State University 11 (186), 223226 (2018)

21. I.N. Rozenberg, Distance and virtual learning 2, 4-8 (2013) 